\title{
DESACELERAÇÃO ECONÔMICA CHINESA: BOLHAS E RECESSÃO
}

\section{Eduardo Aguiar Henrique Filho' Edna Nunes Gurgel de Albuquerque ${ }^{2}$}

Resumo: O presente trabalho pretende mostrar como a expansão de crédito estimulada pelo Banco Central Chinês compactuou severamente para a desaceleração econômica do país, mostrando consequências desta prática monetária, enfatizando o período entre o ano de 2000 a 2016 através de quatro pilares: Bolha Imobiliária, Bolha Especulativa, Endividamento dos Municípios e Capacidade produtiva excessiva. A análise econômica é embasada nos conceitos da Escola Austríaca de Economia, através da Teoria Austríaca dos Ciclos Econômicos (TACE), a qual ensina que recessões e crises econômicas se formam através das seguintes ações da autoridade monetária vigente em determinado território: taxas de juro baixas estimulam a concessão de crédito, aumentando desta forma a oferta monetária. Este aumento leva a um período de crescimento insustentável, em que o dinheiro em excesso procura oportunidades de investimento progressivamente menos rentáveis. Um boom sustentado por uma expansão artificial de crédito leva à uma generalização de maus investimentos.

Palavras-chave: China; Crédito; Bolhas econômicas; TACE.

\footnotetext{
${ }^{1}$ Curso Técnico/Colégio Técnico Univap, Brasil. E-mail: eduardo.ahf@hotmail.com.

2 Curso Técnico/Colégio Técnico Univap, Brasil. E-mail: ednagurgel@uol.com.br.
} 